\title{
Living Hadith: Study of Minimizing Hadith Narration Phenomenon in the Companions' Era
}

\author{
$1^{\text {st }}$ Kiki Adnan Muzaki ${ }^{1}, 2^{\text {nd }}$ Lukita Fahriana $^{1}, 3^{\text {rd }}$ Dewi Khairani ${ }^{2}$ \\ \{kiki_muzaki19@mhs.uinjkt.ac.id¹, lukitafahriana01@gmail.com¹,dewi.khairani@uinjkt.ac.id²\} \\ UIN Syarif Hidayatullah, Islamic Studies Department, Jakarta, Indonesia ${ }^{1}$, UIN Syarif \\ Hidayatullah, Informatics Department, Jakarta, Indonesia ${ }^{2}$
}

\begin{abstract}
This study discusses the discourse of living hadith during the companions' era, especially the phenomenon of minimizing hadith narration. The method used in this research is literature study method by directly examining the hadith books and biographies of the companions as well as journals related to this. The discourse of living hadith has been started since the companions' era, this is evidenced by the phenomenon of many companions who minimized hadith narration, and this was inspired by the hadith of the Prophet related to the threat for anyone who spreads fabricated hadith. There were two forms of the phenomenon of minimizing hadith narration, first not narrating all the known hadith and second forbidding others to narrate the hadith.
\end{abstract}

Keywords: Living Hadith, Companion, Minimizing, Hadith Narration.

\section{Introduction}

The prophet Muhammad peace be upon him is a role model for Muslims, especially for the companions who meet directly with the prophet peace be upon him, his presence among them became a lamp in wading through the darkness of life that's filled by temptations and trials, he is the only figure who became an idol for the companions, they followed him and made him as a role model in all aspects of their life, Allah almighty said in the Qur'an 33:21: "The Messenger of God is an excellent model for those of you who put your hope in God and the Last Day and remember Him often". However, after he passed away there are only two inheritances that become the guide for the Muslims: Al-Qur'an and al-Hadith. The prophet Muhammad peace be upon him said: "I left you something, if you keep it up you will never lost: the Qur'an and the Hadith". [1]

Companions are the first generation of successors to relay Islamic teaching, they are defined as: "every Muslim who meets the Prophet and dies in a state of faith". And they are also categorized as the best generation as the prophet peace be upon him said: "the best of you are the people who live in my century, then the people afterwards then the people afterwards". [5]

The love of the Companions to the prophet peace be upon him made them strongly kept up to the hadith, preserved it and defended it with all their souls, because the hadith is not like the Qur'an which cannot be falsified or modified by anyone. Allah almighty said in 15: 9: "We have sent down the Quran Ourself, and We Ourself will guard it". Therefore, various methods were carried out by them in order to maintain the purity of the Hadith from those who try to 
pollute it with personal interests or their passions. This was done by memorizing the hadith, narrating it, understanding it, exchanging ideas and also living it in everyday life, which is now known as living hadith.

There were so many phenomena that were based on hadith in the companions' era, one of which is minimizing the narration of Hadith and researching the form of living hadith done by the companions is an important thing, besides giving us more references how to live hadith in daily life so that we can revive it in the present, it also become the historical base of living hadith science that's recently referred to be a new branch of the Qur'an and Hadith sciences.

\section{Literature Review}

Two scholars have already done the research in this field, the first one was Adrika Fithrotul Aini, graduate student of UIN Sunan Kalijaga, in her research under the title "Living Hadis Dalam Tradisi Malam Kamis Majelis Shalawat Diba' Bil-Mustofa" he discovered that the existence of "Majelis Shalawat Diba" was inspired by a lot of hadiths about the order to perform shalawat to the prophet Muhammad peace be upon him.

And the second on was Ahmad Muttaqien, he did a research about "Barzanji Bugis dalam Peringatan Maulid: Studi Living Hadis di Masyarakat Bugis, Soppeng", he discussed the phenomenon of celebrating the prophet's birth in Bugis tribe, and the hadith that they are trying to live.

Study about hadith also conducted by Atqia[2] that promotes online searching of hadith to make it more accessible for ummah to search using certain keywords.

\section{Methodology}

This study uses a type of library research by reading reports, journals, books related to the topic especially the book of hadith sciences and biography.

\section{Result and Discussion}

\subsection{The Definition of Living Hadith}

According to Hasbillah living hadith defined as: "The knowledge about the living hadith, or to live hadith in the personal practice or communal practice, cognitively or not". It also can be defined as: "the knowledge to learn about hadith phenomena among human being life".

The term of "living hadith" as a scientific study is a new branch in hadith sciences, however living hadith practically has been started since the time of the prophet peace be upon him and his companions. [3] This can be evidenced by the discovery of some social phenomena as well as individual behavior inspired by hadith in the companions' era. 


\subsection{Living Hadith in The Companions' Era}

There are some differences between the hadith experts regarding who exactly can be categorized as the companions of the prophet peace be upon him, the first opinion says that companion is a Muslim who met the Prophet directly. But this definition is refuted and considered imperfect by other scholars, because based on this definition, if there is a Muslim who met the prophet peace be upon him and died in the state of infidelity, he is still regarded as a companion, and of course this is contrary to the teachings of Islam, therefore the definition of the companions which is considered the most accurate according to al-Suyuti is: "a Muslim who met the prophet peace be upon him and died in a state of Islam". Thus the person who met directly with the prophet peace be upon him and died in a heathen state is not a companion, such as Ibn Khatal. Then based on this definition people who were contemporaries with the prophet peace be upon him but did not meet him also could not be considered as the companions, this group has a special name in the hadith sciences, they are called alMuhadromun. [4]

We can see an individual behavior that's inspired by a hadith in Abu Bakar, he was very clear to people who refuse to pay charity after Prophet Muhammad peace be upon him passed away. It was narrated from Abu Hurairah: when the prophet peace be upon him passed away and Abu Bakar became the leader and some of Arabian became infidel, Umar said "Oh Abu Bakar how can you war against people while prophet peace be upon him said "I have been ordered to war against people until they say la ilaha illallah, who ever said that his wealth and life is forbidden for me except with rightful authority and his responsibility is to Allah". And then Abu Bakar said "I swear to Allah, I will war against who differ between pray and charity, charity is the necessity of wealth, I swear to Allah if they reject to give sheep that they gave to prophet peace be upon him I will definitely war against them because of their rejection". Then Umar Said "I swear to Allah that Abu Bakar has been told by Allah to make war, and I know that is right". [5]

From this hadith we know how Abu Bakar tried to live Qur'an and Hadith which talk about the obligation of charity for every single Muslim, he believed there is no different between pray and charity, both of them are the obligation for Muslim, that was why he made a war against who rejected to pay charity because they broke the law that Qur'an and Hadith fixed.

What Abu Bakar did is a kind of individual behavior phenomena that is inspired by hadith, this kind of living hadith was also performed by Anas bin Malik. It was narrated from Anas bin Malik, he said "there was a tailor invited prophet peace be upon him to food he made, then I go with prophet peace be upon him to that food, then prophet peace be upon him got close to a bread made of wheat and a soup with pumpkin and jerked meat inside, then I saw prophet peace be upon him clean out a plate of pumpkin, and from that day I liked pumpkin. [6] The reason why Anas bin Malik like pumpkin because he saw prophet peace be upon him finished a plate of pumpkin soup in the house of a tailor, then from that day he liked it even though it wasn't his favorite food. These two examples prove us that's living hadith in the shape of individual behavior phenomena had been exist since the companions' era.

Another shape of living hadith that happened in the companions' era is social phenomena, there is a lot of these phenomena we can find in this era, such as when the companions followed the prophet Muhammad peace be upon him to wear the ring and take it off. It was narrated from Nafi' that the prophet peace be upon him made a ring which is made of gold and he put its head on his palm when he wear it, then the people made it also. Afterwards the prophet peace be upon him sat in the podium and took it off and said "I was 
wearing this ring and made its head on my palm" then he threw it away and said "I swear to Allah I will not wear it forever" then the people threw their rings away. [6]

As we see the companions made their own rings when they saw the prophet Muhammad peace be upon him made a ring, they also followed the way how the prophet peace be upon him used his ring, and made their ring from gold just the prophet peace be upon him did. But when they saw him threw it away and wouldn't use it anymore the followed it without doubt. This practice is not an individual behavior, but it's a social phenomenon that's performed by a lot of companion at that time which was inspired by hadis fi'li.

Qiyamu al-lail in Ramadan which is also known as tarawih today is also a kind of social phenomena of living hadith in the companions' era. It was from Aisyah that the prophet peace be upon him prayed in the mosque, then the people prayed as he did, and he prayed the next day, then there was plenteous people, afterwards they assembled in the third day but the prophet peace be upon him did show up. When the sun rises he said "I know what you did, there is nothing obstructs me to show up with you but I am afraid if it will be obligated for you", and that was in Ramadan. [7]Only by watching the prophet peace be upon him perform pray there is a lot of people followed him the next day, this social phenomena also performed continuously even after the prophet Muhammad peace be upon him passed away, this prove the will of companion to live hadith in their life was very dominant.

This kind of living hadith is much more than individual behavior phenomena, neither in the companions' era nor in the modern era, and there is a lot of scholars who have already researched about social phenomena which is inspired by hadith. Such as Siti Qurrotul Aini under the title "Tradisi Qunut Dalam Shalat Maghrib Di Pondok Pesantren Wahid Hasyim Yogyakarta". According to Ainis' research the phenomena of reading qunut at magrib praying in Wahid Hasyim boarding school is inspired by hadith that's narrated by al-Bukhori, Muslim, al-Nasai and al-Tirmidzi. [8] Adrika Fithrotul Aini, did the same thing, her research was: "Living Hadis Dalam Tradisi Malam Kamis Majelis Shalawat Diba' Bil-Mustofa", based on her research the hadith about shalawat has a big influence in establishing this social organization. [9] The other one was Ahmad Muttaqien, his research: "Barzanji Bugis dalam Peringatan Maulid: Studi Living Hadis di Masyarakat Bugis, Soppeng" argued that the people of Sopping are trying to live the hadith about loving the prophet Muhammad peace be upon him. [10]

Wearing ring and qiyamu al-lail were not all of social phenomena in the companions' era, there were other phenomena such as minimizing hadith narration, praying in the mosque, eating with the right hand, praying witr, not using compost, fasting 'Asyura and tasu'a, doing hijamah, table manner and many more, of course all of that were based on the Prophet's peace be upon him hadith.

From the data above, we can see that living hadith has been pioneered and started by the companions, in their time we see how the prophet's guidance in the form of words, action or determination is turned on and actualized in the form of social phenomena and individual behavior.

\subsection{Minimizing Hadith Narration Phenomenon in the Companions' Era}

If we examine more deeply in the biography books of the companions and also some other hadith science books, it turns out that the hadith that reach us today are not $100 \%$ of the 
total hadith known by the companions. This can be seen clearly from the statements of some the companions who admitted that they did not narrate all the hadith they knew. Anas bin Malik for example, he said: "If I were not afraid of being wrong, I would tell you many things that the prophet peace be upon him said". [11] From his statement we know that he didn't narrate all hadith he knew, which means there is a lot of hadith he didn't narrate.

Abu Hurairah also did the same thing, he said "I have memorized two vessels from the prophet peace be upon him, the first one, I spread it, but my throat will be cut if I spread the other one" [4] even Abu Hurairah is known as "muktsir al-Riwayah" but there is another vessels he didn't narrate to the next generation. Ibnu Hajar said: "the hadith experts believed that the hadiths that Abu Hurairah didn't spread them was about the name of tyrannical ruler and their time, therefore he didn't narrate them to protect himself'. [12]

Besides the number of companions who narrated hadith compared to the total amount of companions is totally slight. According to an expert in hadith sciences Abu Zur'ah the total amount of the companions approximately one hundred thousand people. [13] that is very big number, but the companions who narrated hadith to the next generation is not as much as the total amount of them, approximately only 1,800 of 100,000 companions did it. [14]

Chart 1. Number of Companions

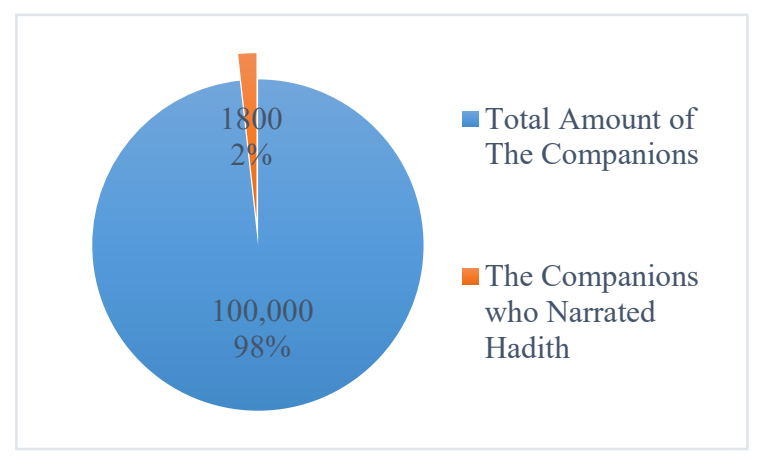

According to Ali, those 1,800 didn't narrate hadith with the same amount, each of them had different amount of hadith that they narrated, seven of them narrated more than 1000 hadiths each, 11 narrated more than 200 hadiths each, 21 narrated more than 100 hadiths each, 10 narrated close to 100 hadiths each, more than 100 narrated close to 10 hadiths each, and more than 300 narrated only one hadith each.[14]

Chart 2. Amount of Hadith Narrated by Companions

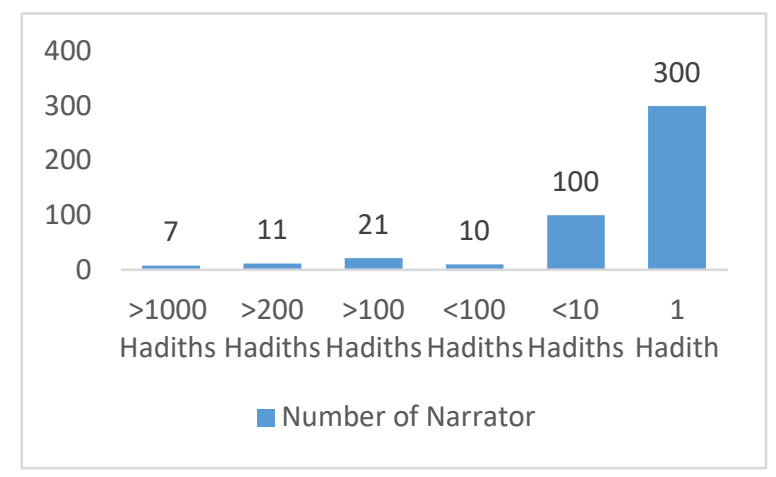


If we see the data above, from approximately 1,800 companions who narrated hadith only several of them did it with a huge number, and most of them minimized that. There is some reasons why the companions didn't narrate hadith massively, such as: being unable to remember hadith perfectly, work, shyness, but the strongest reason is because they tried to live hadith about the forbidden to spread fabricated hadith. The prophet Muhammad peace be upon him said "who lied on my behalf intentionally, then the place of his return is hell" [5] inspired by this hadith, a lot of companions minimized narrating hadith, because they think being too much narrating hadith made a big possibility to make mistake at delivering it. And it is really a big consequence for people who spread false hadiths. In addition, this hadith is mutawatir which is equal to the Qur'an, so that whoever denies it, he has become an infidel, this is certainly very influential for the companions who are very keeping up to the hadith.

This phenomenon started when the prophet peace be upon him passed away, and hadith become very important for Islamic teachings, there were a lot of companions who minimized hadith narration such as Anas bin Malik, Umar bin Khattab, Utsman bin Affan, Zubair bin Awwam, and the others.

\subsection{The Explanation of the Hadith According to Hadith Expert}

It has been mentioned before the hadith that was turned on in the form of social phenomena by the companions, not a few numbers of narrators who narrated this hadith, therefore this hadith considered as mutawatir which is defined as: "The hadith which is narrated by many people that impossible for them to make an agreement to lie" [15]

The credibility of mutawatir Hadith certainly does not need to be doubted, it is higher than Shahih and is equivalent to the Qur'an, and based on the author's observations so far there is no problem making this hadith unable to be practiced, such as: nasakh mansukh, special thing for the prophet peace be upon him or others. Furthermore, understanding the hadith perfectly is not enough just to confirm its credibility, but it is also necessary to interpret the meanings contained in the hadith, in this case many scholars of hadith who have given the explanation of this hadith, such as Ibnu Hajar, Imam Al-Nawawi, al- Qosthollani and others. The explanation of this Hadith in several books of hadith as following:

\subsubsection{Al-Minhaj Syarh Shahih Muslim bin Hajjaj}

Al-Nawawi explained this hadith long enough, including the status of people who lied in the name of the prophet peace be upon him, they are threatened to be put into hell. The question was will they be tortured in hell forever just like infidels?

In this case al-Nawawi revealed that they will not be forever tortured in hell, even though it is mentioned in the hadith that their place to return is hell, but it does not mean forever, because eternity in hell is specifically for those who do not believe in Allah almighty, and the threat in the hadith to show that this practice is very big sins.

Al-Nawawi continues that this hadith only applies to people who lie on behalf of the prophet peace be upon him intentionally, while those who do it by mistake or inadvertently they are not included in this hadith. But it does not mean they are completely innocent, they are sinful because of their ignorance, and therefore studying religion is a necessity for all Muslims especially the hadith which is the fundamental principle in Islam 
Then the scholars also have different opinions related to whether accepted or not the other narration of people who have lied in the name of the prophet peace be upon him. According to Ibn Hanbal, al-Humaidi and some Shafi'I, their narration are not accepted anymore, even though they had repented, (taubat) this is done as a punishment because they made big sin. But according to al-Nawawi this opinion is contrary to the shari'ah rules, that Allah will forgive whoever repents, therefore as long as they have repented the other hadith they narrated can be accepted, as the hadiths of the companions who previously infidel is accepted. [16]

\subsubsection{Irsyad al-Syari}

The text of this hadith is repeated many times in Shahih Bukhori with several additional explanations. It was narrated from Mugirah that he heard the prophet peace be upon him said: "lying in my behalf is not like lying on the name of other person, who lied on my behalf intentionally, then the place of his return is hell".

In this hadith the prophet peace be upon him explained the reason why lying on his behalf is very big sin and threatened to be put into hell, because lying on his behalf is not the same as lying to other Muslims. According to al-Qosthollani this is because the words of the prophet peace be upon him contain the Islamic shari'ah which must be followed by every Muslim until the Day of Judgment. It means that if someone conveyed a false hadith or intentionally made it or narrated wrong hadith then he had indirectly misled Muslims.

The same thing was revealed by Ibnu Hajar when commenting this hadith: "lying in the name of others is lighter, and lying in the name of the prophet peace be upon him is not that light".

Then the question arises, whether to convey the hadith with different text is including a lie on behalf of the prophet or not? In this case the hadith experts have different opinion, for those who forbid it, they believed that the hadith had to be delivered with the same words as the prophet peace be upon him said, there should not be the slightest change even only one letter. But for those who allowed it, they said there is no problem narrating hadith text with a slight different from the words that the prophet peace be upon him said with two condition. First it doesn't change the meaning and second the narrator is an expert in understanding Arabic word. Al-Qostollani said, "If there is an expert narrates hadith text dissimilarly to the prophet's peace be upon him words, than it's allowed according to hadith expert". [17]

\subsection{The Forms of Minimizing Hadith Narration Phenomenon}

The phenomenon of minimizing hadith narration inspired at least has two forms, not narrating all known hadith and forbidding others to narrate the hadith.

\subsubsection{Not Narrating All Known Hadith}

The shape of this phenomenon was done by majority of companions who were inspired by the hadith about the forbidden of narrating fabricated hadith, they prefer to minimize hadith narration, a lot of companions who were very familiar with the the prophet peace be upon him didn't narrate hadith too much, such as Abu Bakr, Zubair, Abu Ubaidah, 'Abbas ibn' abd almutholib, even some of them hardly narrated the hadith at all, like Zaid bin 'amr. [18]

Abu Bakr was the father-in-law of the prophet peace be upon him and the first "Khalifah" who succeeded the prophet peace be upon him after he passed away. Zubair was a cousin of the Prophet, 'Abbas was the uncle of the Prophet, Abu Ubaidah was the first person 
who converted to Islam and was praised as a trusted person. Even though they were the closest companions to the prophet Muhammad peace be upon him the hadith they narrated was not much.

Anas bin Malik was the one who performed this phenomenon, he clearly mentioned the reason he didn't narrate all hadiths he knew. He said: "if I were not afraid of being wrong, I would tell you many things that the prophet peace be upon him said, but I heard him said: "who lied on my behalf intentionally, then the place of his return is hell"". [11]

Anas bin Malik was one of the companions who spent many time with the prophet peace be upon him, this was because he was his servant, so he witnessed many words and deeds of the Prophet compared to other the companions. [19]

Anas bin Malik also known as the seven companions who narrated many hadith from the prophet peace be upon him or "Muktsirun al-Riwayah", according to Ibn al-Jauzi he narrated 2286 Hadiths, [20] even so it doesn't deny the fact he didn't narrate all hadith he memorized as he stated, as the servant of the prophet peace be upon him he must know more than 2286 hadith, his narration is slight compared to Abu Hurairah who narrated 5374 hadith in three years with the prophet Muhammad peace be upon him, and Anas bin Malik spent more time with the prophet peace be upon him than Abu Hurairah, so he definitely memorized more than 2286 hadith but still he didn't narrate them all.

The other companion who didn't convey all hadith he heard was Umar bin Khattab, according to Ibnu Mulqin he narrated 539 hadith. [21] Considering him as father in law of the prophet Muhammad peace be upon him, and one of "Khulafa al-Rasyidun" there must be a lot of thing he knew about him, but only 539 of them he narrated, the reason is because he was afraid to make mistake when delivering it.

It was narrated from Dujain bin Tsabit, he said: "we was saying to Umar "Tell us the hadith from the prophet peace be upon him" then he replied: "I am afraid of making addition or diminution, and I have heard him said: "who lied on my behalf intentionally, then the place of his return is hell"'". This hadith was inspiring Umar not to tell the hadith plenteously, and he thought a little bit addition or diminution will be considered as spreading fabricated hadith which is threatened to be put in the hell, that is why even though his servant Dujain asked him to narrate hadith he won't do it.

This phenomenon which was inspired by the hadith was also clearly done by Usman bin 'Affan, he said: "The thing that caused me didn't narrate the hadith from the prophet peace be upon him is not because I am not a companion who knows him well, it because I witnessed him said: "who said on my behalf what I didn't say, then the place of his return is hell"”. [11]

Utsman had a designation which was given because he married two daughters of the prophet Muhammad peace be upon him, Ruqayyah and Ummu Kultsum, he was called "Dzu Nurain". He was also one of "Khulafa al-Rasyidun" and he spent many time with the prophet peace be upon him, that's why he was one of the closest companions to him, and knew him well as he said, but if we read book of hadith we will not find the hadith he narrated except some.

It was narrated from 'Abdullah bin Zubair that he asked Zubair bin Awwam: "Why didn't I hear you narrating the Prophet's hadith as I heard Ibn Mas'ud and someone and someone?" Then he replied "actually I have never parted from the prophet peace be upon him since I converted Islam, but I heard him said: "who lied on my behalf intentionally, then the place of his return is hell"'. [22]

Zubair bin Awwam was the fourth person who converted to Islam, he was the prophet's peace be upon him cousin and his advisor. The prophet Muhammad peace be upon him said "if every messenger of Allah has an adviser then my adviser is Zubair bin Awwam".[23] He was 
that close to the prophet peace be upon him but his own son 'Abdullah felt that's he didn't narrate too much hadiths until he asked him.

Based on the data above we can find out how a hadith text was turned into the form of social phenomena, this happened because their love is so deep towards the prophet Muhammad peace be upon him, then all of his guidance was lived in daily life. And Malik bin Anas considered their actions as one of the source of Islamic shari'ah which is also known as "amal ahl al-madinah". [3]

\subsubsection{Forbidding Others to Narrate the Hadith Plenteously}

Besides holding self to narrate all the known hadith, the phenomenon of minimizing hadith was also realized in the form of prohibiting others to narrate hadith plenteously, this was done by the companion who was respected by other companions, such as Abu Bakar and Umar.

It was narrated from Abu Mulaikah that Abu Bakar gathered the companions after the prophet Muhammad peace be upon him passed away and said: "don't narrate the hadith that you disputed, and generations after you will dispute it more, then don't narrate the prophet Muhammad peace be upon him hadith, whoever asked you then reply them by saying: "we have the Qur'an, allow what Qur'an allows and forbid what Qur'an forbid".[24]

The statement of Abu Bakar was very clear forbidding the companions to narrate the hadith, but according to al-Dzahabi Abu Bakar didn't forbid the companions to narrate the hadith at all, this was done so that the companions didn't narrate the hadith carelessly. [24] Abu Bakar was also afraid that if too many hadiths are narrated, the Muslims will also have many disputations and divisions.

The next figure who realized this phenomenon was Umar bin Khatab, he was a very strict figure and was also feared by other the companions. Ibn Qutaibah said: "Umar is a hard figure against people who narrated hadith excessively, or narrated hadith without witness, and he ordered the companions to minimize the narration of hadith, so that they were not spread too much and were not mixed with the false hadith of the hypocrite, and fools". [25]

The same thing also expressed by 'Ijaj: "Umar was very hard in practicing this method, he ordered the companions to confirm the hadith they heard, and minimize their narration, and he has a great service in keeping the hadith from falseness". [18]

Umar's command to minimize the transmission of hadith was apparently heard and followed by the companions, besides his firmness and authority, the companions also knew that Umar did it to prevent lie on behalf of the prophet Muhammad peace be upon him. This was evidenced by Abu Hurairah who did not dare to narrate the hadith plenteously when Umar was still alive. It was narrated from Abu Salam that he asked Abu Hurairah: "Do you narrate the hadith at the present of Umar like this?" Then he replied: "If I narrate the hadiths at the present of Umar as I narrated them to you, he will beat me with his whip". [25]

Abu Huarairah was one of the companions who narrated many hadiths, and of course he narrated it after Umar passed away. So why did Abu Hurairah narrate the hadith in large quantities? Wasn't he afraid of being wrong in his transmission? related to this matter Abu Hurairah once said: "I am a poor man who always follows the Prophet because of my stomach, while muhajirin are busy trading in the market, and anshor are busy with their property, I attend an assembly with the Messenger of Allah peace be upon him, then he said: "whoever spreads his turban when I present my hadith and close it again will never forget what he heard from me". Then I spread my turban until he finished speaking and he covered it for me, I swear to Allah, I have never forgotten what I heard from the prophet after that".[26] 
From Abu Hurairah's statement we can understand that Abu Hurairah believed that he never forgot the slightest hadith that he had heard from the prophet Muhammad peace be upon him, because he had been prayed directly by the prophet peace be upon him. Base on this he had the courage to narrate the hadith in large numbers.

Umar's clearness in minimizing the narration of hadith can be seen when he imprisoned some of the companions whom he thought narrated too many hadith. It was transmitted from Ibrahim that Umar imprisoned three companions, namely: Ibn Ma'ud, Abu Darda, and Abu Mas'ud al-Ansari. Then he said: "You have narrated too many hadiths from the prophet peace be upon him". [24]

Umar's actions did looked a bit excessive if he had to imprison some the companions for narrating the hadith, but this phenomenon really happened during Umar's time, and he also didn't do it because of personal vengeance or lust, he did it to maintain the purity of the hadith which is the second source of shari'ah after the Qur'an.

At last what the companions did to live this hadith can be a model to revive the hadith in the modern era, the hadith "who lied on my behalf intentionally, then the place of his return is hell" can be revived today by not too much delivering hadith except if it credibility has been confirmed, and being sure not to make an error at delivering it.

\section{Conclusions}

Social phenomena or individual behavior that's inspired by the hadith better known as the Living Hadith have started since the companions' era. This can be seen clearly from the majority of their activities that were truly in accordance with the guidance of the prophet Muhammad peace be upon him, and one of them was the phenomenon of minimizing hadith narration, this phenomenon was inspired by a hadith: "who lied on my behalf intentionally, then the place of his return is hell". There were two forms of the phenomenon of minimizing hadith narration, first not narrating all known hadiths, Anas, Umar, Utsman, Zubair bin 'Awwam were who performed it. The second would be prohibiting others to narrate hadith plenteously, as Abu Bakar and Umar did.

Acknowledgements. This research supported by The Graduate School of Islamic Studies UIN Syarif Hidayatullah.

\section{References}

[1] al-Baihaqi, A.: Sunan al-Kubra. Dar El-Kutub Al-Alamiyah, Beirut (2003)

[2] A. Aulia, D. Khairani, and N. Hakiem, "Development of a retrieval system for Al Hadith in Bahasa (case study: Hadith Bukhari)," in 2017 5th International Conference on Cyber and IT Service Management, CITSM 2017, 2017.

[2] Hasbillah, A.: Ilmu Living Quran-Hadis, Ontologi, Epistemologi, dan Aksiologi. vol. 1. Maktabah Darus-Sunnah, Ciputat (2019)

[3] al-Suyuthi, J.: Tadrib al-Rawi Fi Syarhi Taqrib al-Nawawi. vol. 1. Dar el-Bayan 'Arabi, Cairo (2004)

[4] al-Bukhori, M.: Shahih Bukhori. Dar Ibnu Katsir, Beirut (1987)

[5] Hajjaj, M.: Shahih Muslim. vol. 9. Dar el-Hadith, Egypt (2001)

[6] Abadi, M. 'Aun al-Ma'bud. vol. 7. Dar el-Hadith, Cairo (2005) 
[7] Aini, SQ.: Tradisi Qunut dalam Shalat Maghrib di Pondok Pesantren Wahid Hasyim Yogyakarta (Studi Living Hadis). Jurnal Living Hadis. pp. 227-241 (2017)

[8] Aini, AF.: Living Hadis dalam Tradisi Malam Kamis Majelis Shalawat Diba'Bil-Mustofa. Ar Raniry: International Journal of Islamic Studies. pp. 159-172 (2015)

[9] Muttaqin, A.: Barzanji Bugis dalam Peringatan Maulid: Studi Living Hadis di Masyarakat Bugis, Soppeng, Sul-Sel. Jurnal Living Hadis. pp. 129-150 (2016)

[10] al-Jurjani, A.: Al-Kamil Fi Ma'rifati Dhu'afa Muhadditsin Wa 'Ilal Hadist. Dar El-Kutub AlAlamiyah, Beirut (1997)

[11] al-Asqolani, IH.: Fathu al-Bari Bi Syarhi Shahih al-Bukhori. Dar el-Hadith, Cairo (2004)

[12] al-Zarkasyi, B.: Al-Nukat 'Ala Ibnu Al-Sholah. Adwa Al-Salaf, Riyadh (1998)

[13] Gomaa $\quad$ A.: $\quad$ Ruwat al-Hadis Min http://www.draligomaa.com/index.php/\%D8\%A7\%D9\%84\%D9\%85\%D9\%83\%D8\%AA\%D8\%A 8\%D8\%A9/\%D9\%85\%D9\%82\%D8\%A7\%D9\%84\%D8\%A7\%D8\%AA/\%D8\%A7\%D9\%84\%D8 \%A3\%D9\%87\%D8\%B1\%D8\%A7\%D9\%85/item/1677-\%D8\%B1\%D9\%88\%D8\%A7\%D8\%A9\%D8\%A7\%D9\%84\%D8\%AD\%D8\%AF\%D9\%8A\%D8\%AB-\%D9\%85\%D9\%86$\% \mathrm{D} 8 \% \mathrm{~A} 7 \% \mathrm{D} 9 \% 84 \% \mathrm{D} 8 \% \mathrm{~B} 5 \% \mathrm{D} 8 \% \mathrm{AD} \% \mathrm{D} 8 \% \mathrm{~A} 7 \% \mathrm{D} 8 \% \mathrm{~A} 8 \% \mathrm{D} 8 \% \mathrm{~A} 9-$ \%D8\%B1\%D8\%B6\%D9\%88\%D8\%A7\%D9\%86-\%D8\%A7\%D9\%84\%D9\%84\%D9\%87\%D8\%B9\%D9\%84\%D9\%8A\%D9\%87\%D9\%85 (accessed August 23, 2019).

[14] Thahan, M.: Taisir Mustholah Hadist. Dar El-Fikr, Beirut n.d.

[15] al-Nawawi, M.: Al-Minhaj Syarh Shahih Muslim bin Hajjaj. Dar al-Ihya al-Turast al-'Arobi, Beirut (1973)

[16] al-Qosthollani, S.: Irsyad al-Sari Li Syarhi Shahih al-Bukhori. Al-Matba'ah al-Kubra al-Amiriyah, Egypt (1906)

[17] 'Ijaj, M.: Al-Sunnah Qabla al-Tadwin. Dar El-Fikr, Beirut (1980)

[18] al-Asqolani, IH.: Al-Ishobah Fi Tamyiz Al-Shahabah. Dar El-Kutub Al-Alamiyah, Beirut (1995)

[19] al-Jauzi, A.: Talqih Fuhum Ahl Atsar Fu 'Uyun al-Tarikh Wa al-Sair. Dar El-Arqom, Beirut (1997)

[20] Mulqin, SI.: Al-I'lam Bi Fawaid 'Umdatu al-Ahkam. Dar El-'Ashimah, Saudi Arabia (1997)

[21] al-Qozwaini, M.: Sunan Ibnu Majah. Dar el-Hadith, Egypt (2010)

[22] Atsir, 'I.: Usud al-Ghobah Fi Ma'rifati al-Shahabah. Dar El-Kutub Al-Alamiyah, Beirut (1994)

[23] al-Dzahabi, M.: Tadzkirah al-Huffadz. Dar El-Kutub Al-Alamiyah, Beirut (1998)

[24] Qutaibah, M.: Tawil Mukhtalaf Hadist. 2nd ed. Muassasah al-Isyraq, Yemen (1999)

[25] al-Mizzi, Y. Tahdzib al-Kamal. Muassasah al-Risalah, Beirut (1980) 